Renato Oblak, M.Sc.

E-mail: renato.oblak@ri.htnet.hr

Mack d.o.o. Project Management, Nikole Tesle 9, 51000 Rijeka, Croatia

Svjetlana Hess, Ph.D.

E-mail: shess@pfri.hr

Alen Jugović, Ph.D.

E-mail: ajugovic@pfri.hr

University of Rijeka, Faculty of Maritime Studies, Studentska 2, 51000 Rijeka, Croatia

\title{
Inland Container Terminals in the Function of the Northern Adriatic Ports Enhanced Operation
}

\begin{abstract}
Continuous growth in the Northern Adriatic ports container traffic has caused a high utilization rate of the existing loading/unloading and storage capacities. In order to relieve pressure in ports and avoid traffic congestion and overcrowding which are already occurring, a possible solution is imposed by the construction of a new inland container terminal in their catchment background. This would meet the need for additional storage areas, speed up the flow of containers and ensure sustainable development of the Northern Adriatic container ports. In this paper, a proposition is presented for development of an inland container terminal in Kotoriba as a transit logistics centre for the ports of Rijeka, Trieste and Koper. Using the concept of their transport interlinkage and business policy pursuing their common appearance on the market, unlimited possibilities will be provided for the development of the Northern Adriatic supply chain toward the markets of the Central and Eastern Europe.
\end{abstract}

Key words: inland container terminal, Northern-Adriatic supply chains, logistical planning, intermodal transport

\section{Introduction}

Liberalization of the world market and geographical distribution of raw materials and industrial production have led to a constant increase in the port freight traffic [1]. This puts a lot of pressure on the limited capacity of ports which must ensure smooth running of loading/unloading operations with the available infrastructure and 
equipment. Under such circumstances, the highest long-year growth is presented by container traffic which achieved a total annual turnover of over 687 million TEUs [2] through container terminals in 2014 (Figure 1).

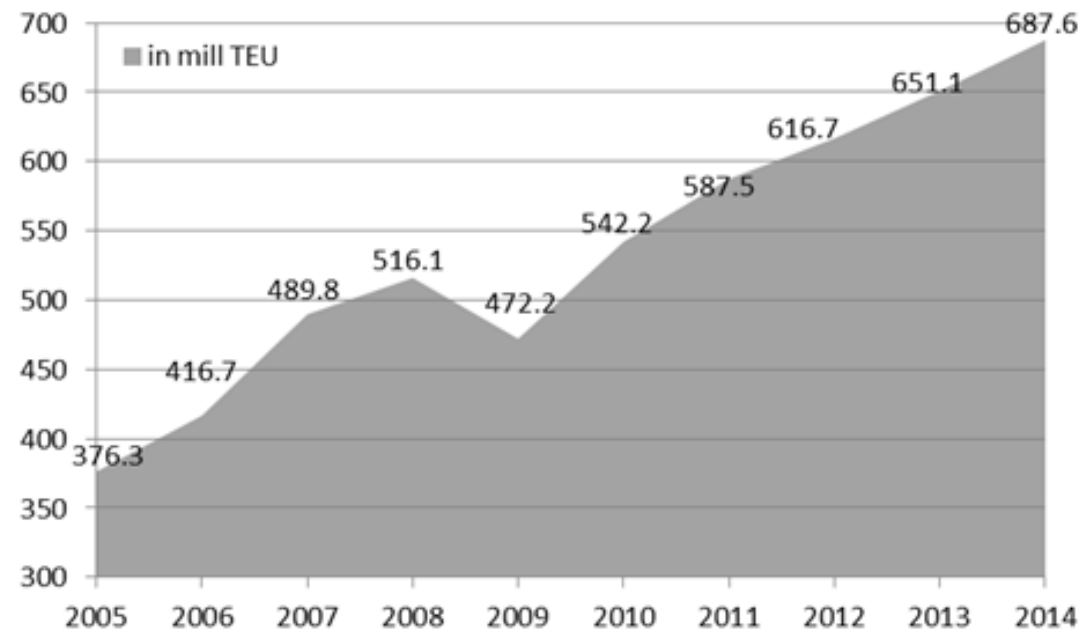

Figure 1 -Display of the total annual port container turnover [2]

Port container traffic measures the flow of containers from the land to the seaborne transport modes and vice versa, in twenty-foot equivalent units (TEUs), a standardsize container. The data refer to coastal shipping as well as to international trade. The loading/unloading traffic is counted as two lifts at the intermediate port (once as an off-load and again as an outbound lift) inclusive of empty units.

In this way, container terminals have become major hubs in facilitating global supply chains, while their size is determined by the level of direct connection with strong local markets and/or transit attraction to distant regions that generate transport needs [3]. Accordingly, Table 1 shows the total annual turnover in 20 of the world's largest container ports.

With the increase in container turnover, port connections with the hinterland have become a crucial factor in achieving a more competitive position in the market. Therefore, developing just the coastal parts of port terminals, without corresponding improvements in the availability of land, is not enough for the smooth functioning of transport processes [5]. This is also due to the introduction of larger container ships that have created strong pressure on port terminals which, in avoiding overcapacity and creating frequent traffic congestion, must seek appropriate solutions in the distribution of containers to inland terminals [6]. In such an expansion, the most important link is seen in good connections based on available capacities of the road and railway infrastructure, as well as on access to inland waterways [7]. 
Table 1 - Turnover in 20 of the world's largest container ports in 2014 [4]

\begin{tabular}{|l|c|}
\hline \multicolumn{1}{|c|}{ Port, Country } & Turnover in mil. TEU \\
\hline 1. SHANGHAI, CHINA & 35.29 \\
\hline 2. SINGAPORE, SINGAPORE & 33.87 \\
\hline 3. SHENZHEN, CHINA & 24.04 \\
\hline 4. HONG KONG, CHINA & 22.23 \\
\hline 5. NINGBO - ZHOUSHAN, CHINA & 19.45 \\
\hline 6. BUSAN, SOUTH KOREA & 18.68 \\
\hline 7. QINGDAO, CHINA & 16.62 \\
\hline 8. GUANGZHO HARBOR, CHINA & 16.63 \\
\hline 9. JEBEL ALI, DUBAI, UAE & 15.25 \\
\hline 10. LOS ANGELES/LONG BEACH, U.S.A. & 15.16 \\
\hline 11. TANJIN, CHINA & 14.05 \\
\hline 12. ROTTERDAM, NETHERLANDS & 12.30 \\
\hline 13. PORT KELANG, MALAYSIA & 10.95 \\
\hline 14. KAOHSIUNG, TAIWAN, CHINA & 10.56 \\
\hline 15. DALIAN, CHINA & 10.13 \\
\hline 16. HAMBURG, GERMANY & 9.78 \\
\hline 17. ANTWERPEN BELGUIM & 8.98 \\
\hline 18. XIAMEN, CHINA & 8.57 \\
\hline 19. TANJUNG PELEPAS, MALAYSIA & 8.52 \\
\hline 20. LAEM CHABANG, THAILAND & 6.58 \\
\hline
\end{tabular}

The problem of the Northern Adriatic container ports, as highlighted in this paper, is the utilization of existing loading/unloading capacities, as well as the level of their connection with the inland terminal. In accordance with the results obtained and actual studies on trends in the future movement of container traffic of the Northern Adriatic transport route, the aim of this paper is to propose the implementation of a new inland container terminal that could improve the supply chains to the markets of the Central and Eastern Europe.

\section{Previous research}

Through a brief review of the relevant literature concerning the concept of linking sea ports to inland terminals, the thoughts of individual authors will be presented and the framework guidelines as the basis for this study will be specified. 
Notteboom [8] analyzes the connection port with the hinterland from the perspective of the significance of the role that individual participants in the transport chain have. Observed in these correlations is the level of influence of the port authorities, shipping companies, terminal and transport operators and the logistics service provider. The main stated fact is the permanent competitive struggle going on between individual seaports in winning the leading position in internal markets. In doing so, their main weapon is the offer of intermodal services which implies a direct dependence on intermodal operators. In their success, the most important link is the port authority that can ensure better synergy effects with other transport hubs and other participants of logistics networks of which they are a part.

Given the constant increase in the volume of container traffic and pressures of container ships with increasing capacities, Acciaro and McKinnon [7] indicate that with the increase in the coastal port capacity, the land transport infrastructure should not be neglected since it will have to be able to efficiently distribute the ever increasing volume of cargo. The authors identify three major segments that determine the supply chains of sea ports with the hinterland. This includes the system management terminal, road and rail links with the market, and inland terminals. In order to reduce the risk of traffic congestion, overcrowding and pollution, coordination between these three elements must be fully harmonized.

The concept of direct rail connections of seaports with inland terminals is suggested and elaborated by Roso, et al. [9]. In this connection, they see the many benefits that can be seen in ensuring a strong link with markets of interest, as well as better and higher quality transport service. According to them, the most important benefit of such links is considered to result from reduction in the level of environmental pollution in relation to road transport. Besides, inland container terminals are categorized according to spatial distance in three basic groups: the distant, distant secondary and those located in the immediate vicinity.

There are many participants involved in the process of land shipment and transport of containers such as shipping companies, companies that manage ports and inland terminals, international shippers, providers of land transport services, port authorities, customs services and many others. Each one is characterized by different interests, business tasks and objectives, and therefore many of the problems can also appear in their mutual coordination. The analysis of the quality of their mutual coordination with organizational aspects of cooperation deals is found in the work of Van Der Horst and De Langen [10]. They warn that coordination problems generally stem from disparities between the costs and benefits of mutual harmonization, lack of desire to invest, different strategic considerations of the parties involved and risk-averse behaviour. As a possible solution, they propose application of four basic models, namely: introduction of incentive contracts, alliance between the companies, changing of goals or the creation of joint action.

The benefits of the development of sea ports by applying the concept of transport links with main inland terminals in the hinterland are analyzed by Jaržemskis and 
Vasiliauskas [11]. As the mode of such an expansion, they propose the development of ports as a logistics platform that will better evaluate and meet the different needs of the consignor and consignee of goods and establish closer business partnerships with them. This has contributed to the increasing internationalization of port operations which, for compliance with the growing demands of the market, must be as precise as possible to find out and collect all the new insights that appear there. Therefore, the port proposal must provide a growing number of additional services that can be supplied only with the assistance of inland terminals. In doing so, they are only limited by the availability and efficiency of the land transport infrastructure, as well as the logistical ability of transport operators.

\section{Inland container terminals}

Container traffic starts at the moment of loading the cargo in a container and ends with its unloading. These are the most demanding operations in the entire transportation process since the manipulation of different types of cargo requires a high-quality level of labour training, high level of technical equipment, as well as an adequate infrastructure with sufficient area of open and closed working spaces. Since the container terminals at sea ports are mainly oriented to the processes of transhipment from ships, wagons, trucks and barges, the processes of loading and unloading of containers are carried out in other locations. These locations can be in the immediate vicinity, distant inland container terminals and warehouses of importers and exporters.

The most important factors in the selection of the location for container stuffing/ unstuffing are: price, availability of the necessary technical equipment, speed and quality of services.

Locations near the container terminals are characterized by high container reloading costs caused by large capital investments in facilities and equipment located in expensive areas around major sea ports as well as by high local transportation costs.

Container reloading at user-owned warehouses is conditioned by the level of technical equipment requiring large financial investments and by the time and space limitations of other available capacities.

Therefore, the optimal solution to the container reloading problem is the development of an inland container terminal based on the concept of interconnection of different types of cargo and containers at one location with low reloading prices, which would enable a large number of additional cargo operations.

With the introduction of containerized shipping, the traditional system of maritime transportation on the "port to port" basis was completely changed. Application of new technologies and an improved logistical approach have stimulated rapid growth in the multi-modal transport. Inland terminals have thus become the main drivers toward better exploitation of the land infrastructure. This has increased the efficiency of the entire international transportation network and has included inland terminals in 
an expanded logistical function of seaports. The reasons that contributed to the rapid formation of inland terminals are [12]:

- constant need for improvements in the land transport efficiency,

- increasing incidences of traffic congestion in areas around major ports with the lack of free space for manipulation with the growing volume of container traffic and

- transformation of maritime transport activities "from port to port" into an integral component of broader logistics operations.

The areas for the planned inland terminals are dependent on a number of different factors that reflect the different levels of their attractiveness. The most important among them are [13]:

- distance from sea ports,

- vicinity of important transport corridors,

- frequency of cargo flows,

- possibilities for expansion of the terminal,

- proximity to important industrial, transport and economic centres at local and regional levels,

- availability of quality workforce,

- level terminal multimodality,

- land prices,

- political structures, and other.

Defining the inland terminals with regard to their purpose and role in the transport processes is a very complex task. But according to the authors Jaržemskis and Vasiliauskas [11], the inland terminal transport is a hub located in the interior which serves industrial and/or commercial regions by connecting them (by rail and/or road and/or inland waterways) with one or more sea ports with the provision of services.

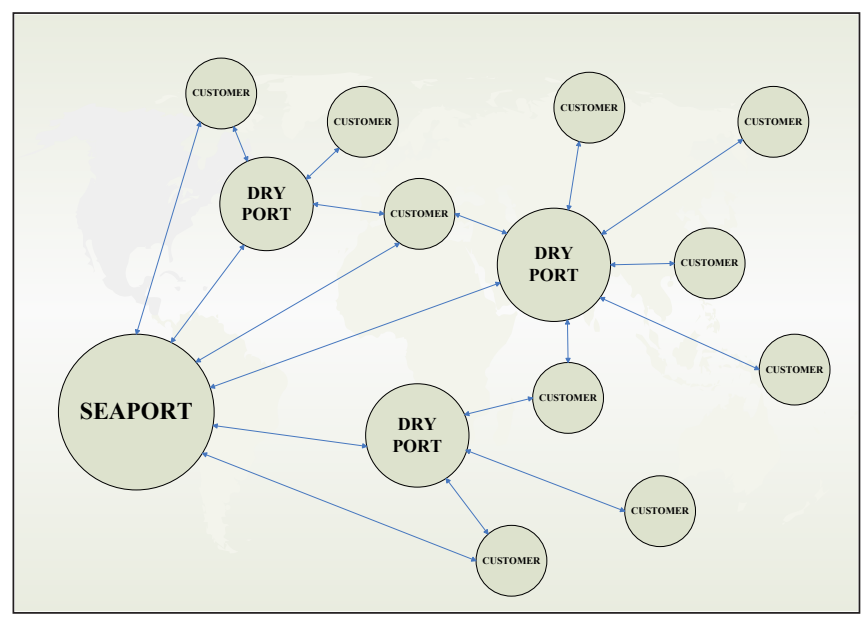

Figure 2-Display of inland container terminals in supply chains 
Within the inland terminals, different kinds of services can be provided which, depending on the available infrastructure and equipment, can be divided into [14]:

- basic logistics services: intermodal connections, cargo handling, loading, unloading, handling and loading of containers, temporary storage, distribution centre,

- value-added services: collection, compilation and distribution of the burden, charging and discharging of LCL containers, quality control, inspections of goods, packing, repacking, customs clearance of goods, cargo insurance, repairs, maintenance and cleaning of containers, shipping services, and

- commercial and financial services: restaurants, financial institutions, accommodation, health and medical services, retail stores, security services.

Based on the variety of services that inland terminals have in their offer, they improve port supply chains and contribute to their better, faster and more efficient pattern. The most important advantages that they provide are [15]:

- concentration centre for remote cargo and its consolidation,

- providing maintenance services for cargoes,

- facilitating customs clearance of goods near the production and consumption centres,

- reducing costs due to time-wasters and theft,

- unnecessary customs procedures in seaports,

- issuing of multimodal bill of lading by shipping companies with extended transport liability and model of delivery of cargo on a "door to door" principle,

- reducing the overall level of movement of empty containers,

- contribution to achieving competitive transport costs,

- reducing costs caused by the unnecessary inventory and

- increasing the international trade.

Without the development of inland terminals, the sustainable and efficient functioning of seaports today would be completely unthinkable. Therefore, in any strategic planning of port supply chains, special attention should be paid to quality land links with the hinterland. Only in this way can they create a widespread logistics network where port terminals will provide intermodal service to a wide catchment area.

\section{Logistics network of the northern-adriatic container ports}

Container traffic between Europe and other parts of the world in the past fifteen years has changed dramatically. This has contributed significantly to the imports of finished products from the Far East because of China's entry into the World Trade Organization in 2001 and the integration of the Central and Eastern Europe into the European Union in 2004 with its dynamic economies. This caused the creation of new container supply chains that are now facing the Southern and Eastern Europe [16]. 
Such a development of the market situation was most favourable for the development of the Northern Adriatic container traffic ports which, considering the linear connection between the Far East through the Suez Canal, make the shortest route to the Central and Eastern European countries in relation to European ports of the North. This is evident from the continuous growth of the total container traffic in the Northern Adriatic ports (Figure 3).

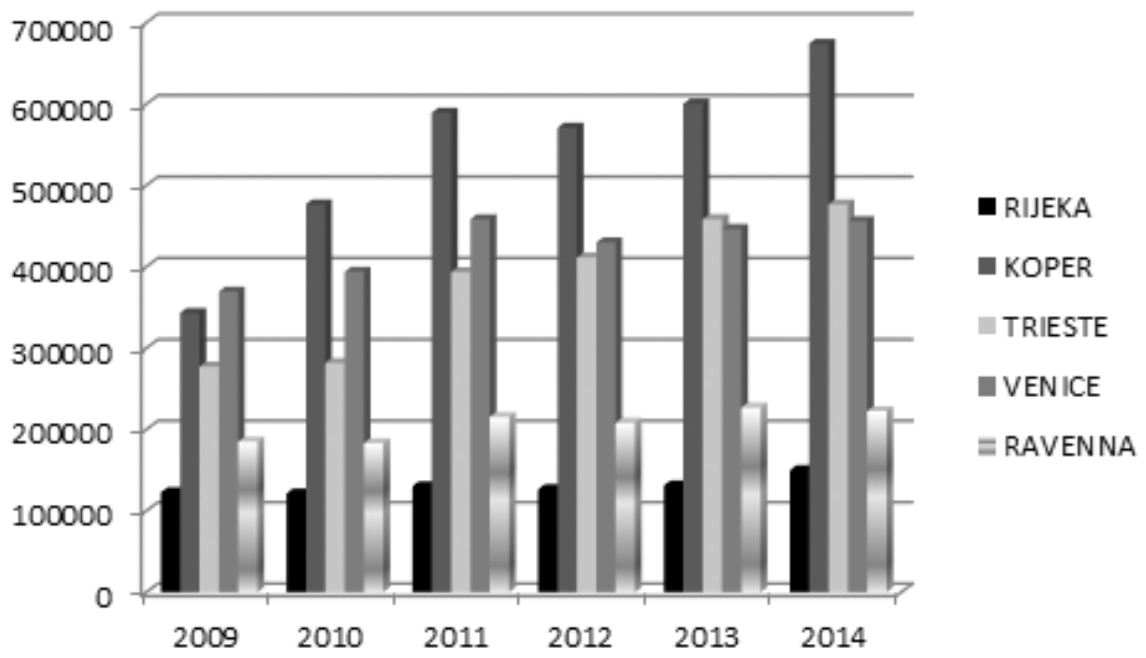

Figure 3 - Display of the total container turnover in the Northern Adriatic ports (in TEUs) [17-22]

In addition to the analyses of the NAPA organization of potential future market needs in the container sector concerning the ports of the Northern Adriatic [16], during the period 2010 to 2030 the total turnover should be increased by up to $348 \%$. This will create a strong pressure on the existing port capacity (Figure 4), which will have to look for solutions in the quality of transport connections with the internal market using the advantages offered by inland terminals. 


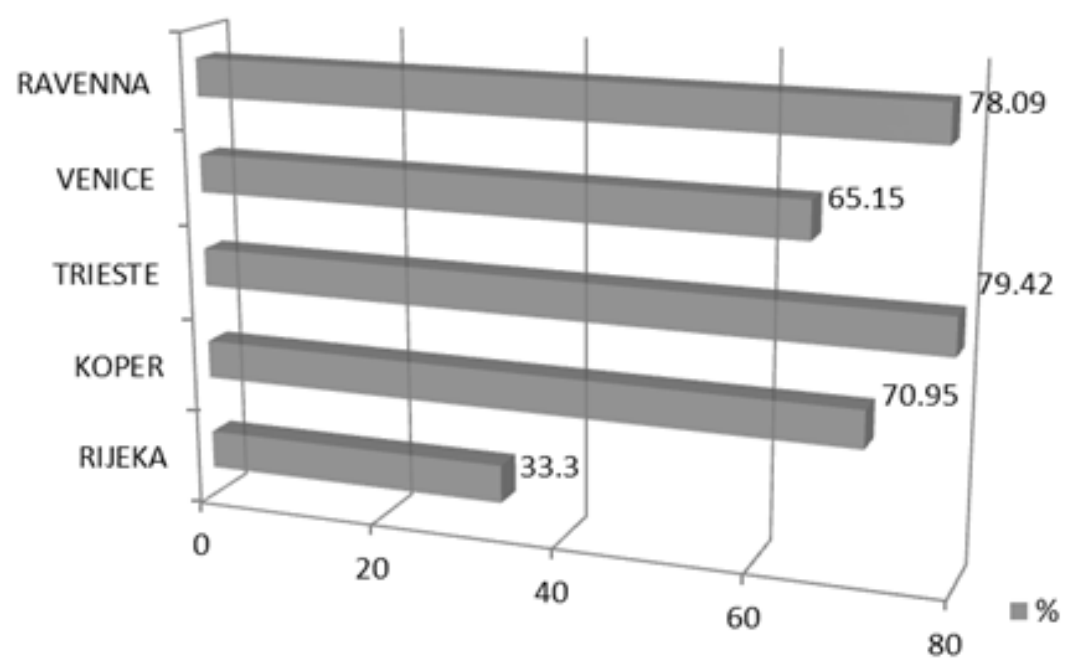

Figure 4-Utilization of existing capacities of container terminals in the Northern Adriatic for the year 2014 [17-22]

In such a logistical planning, the most important criterion for sustainable development of future inland terminals will be the level of their intermodality, loading/ unloading pricing policy, pricing manipulation, offered conditions regarding the free time of storage billing and amount, service of customs and customs clearance of goods, and other administrative and technical facilities. The availability of intermodal terminals, which are now in support of container terminals in the Northern Adriatic transport routes to Croatia, Slovenia, Austria, Hungary and Slovakia, are shown in Figure 5. 


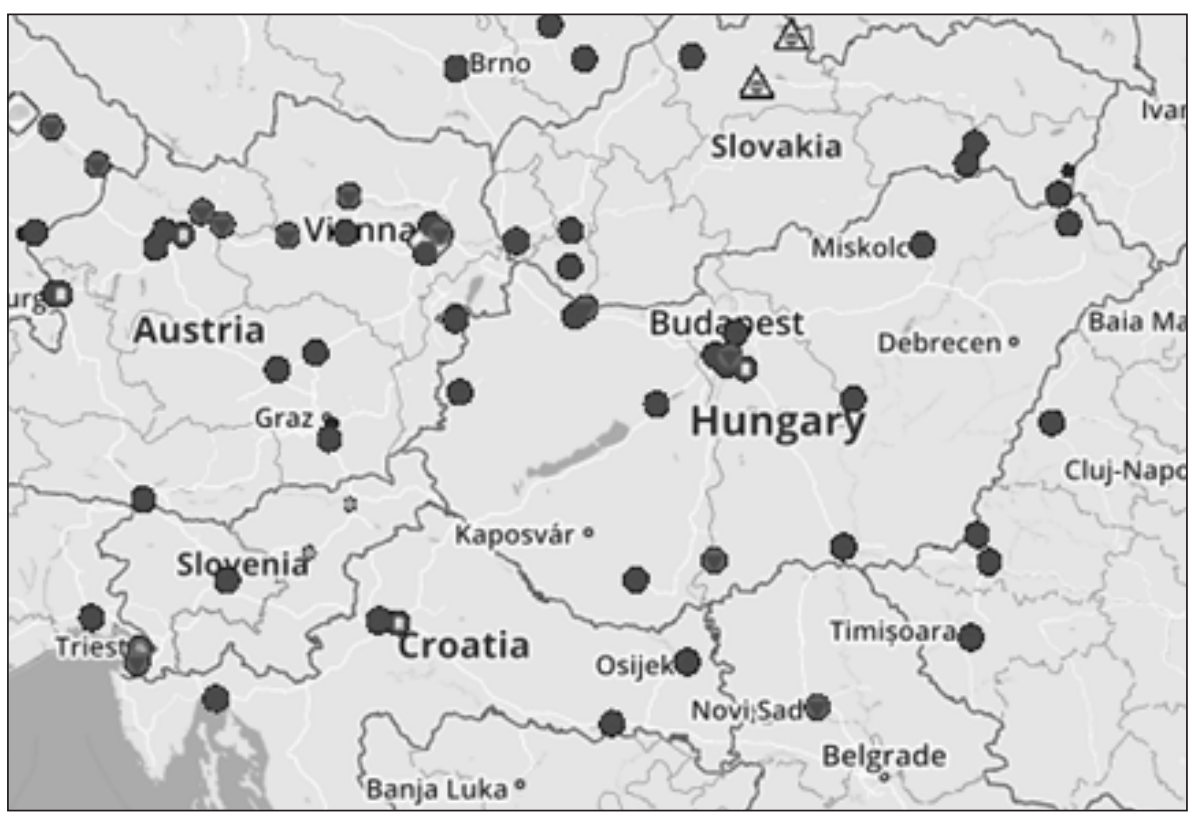

Figure 5-Inland terminals in the catchment hinterland of the Northern Adriatic [23]

Given the closeness of container terminals in Trieste, Koper and Rijeka and the relatively low capacity catchment of regional and national markets, in order to increase traffic the stated ports will need to look in more distant markets in the Southern Germany, Austria, Central and Eastern Europe. This will be achieved only by developing efficient and fast rail connections to these markets, which will be directly reflected in the development of inland terminals that will need to be located in the major railway hubs.

\section{The new proposal of inland terminal in kotoriba, croatia}

Common market orientation, the increase in traffic and limited capacity in the ports of Rijeka, Trieste and Koper have led to the rapid need for new transport solutions in the land distribution of containers. The development of a new inland container terminal that would be in their mutual logistical function is imposed as a real and ideal solution.

The basic concept of inland terminals is based on traffic mediation between seaports and their interest markets while providing a certain level of services. Therefore, in their planning as transport hubs, the transport network must especially observe numerous elements that determine them, such as:

- land availability and price,

- transportation links with one or more sea ports,

- availability of transport infrastructure (road, rail and / or inland waterways) 
- distance and size of shopping centres in the region,

- economic power of potential location,

- cheap labour,

- diversity of services provided at the terminal, etc.

Depending on the level of implementation of the mentioned elements, they will depend on the quantitative and qualitative valuation of individual locations for the development of inland terminals, which will directly reflect on their future business success.

By analyzing all the relevant factors that affect the attractiveness of such a terminal, which would also be in the common interest of the container ports of the Northern Adriatic in the direction of their stronger appearance on the competitive market, the inland terminal in Kotoriba, Croatia is imposed as a possible solution (Figure 6).

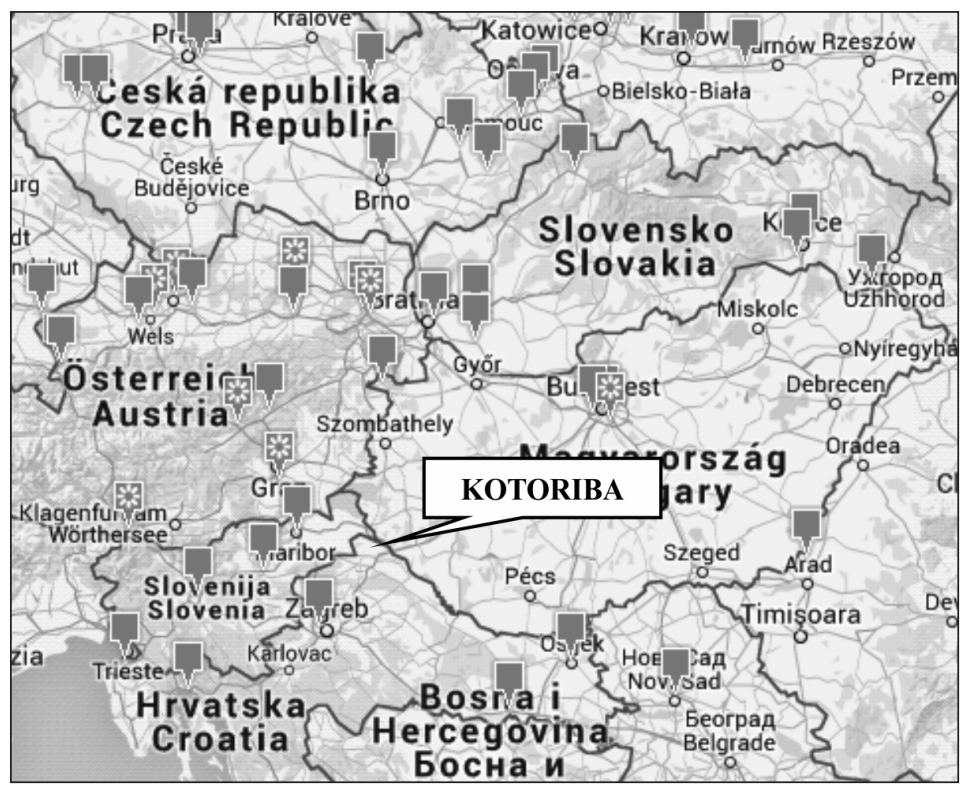

Figure 6-Location of the inland container terminal in Kotoriba, Croatia [23]

The main reasons that have contributed to such a selection are:

- direct rail and road links of Kotoriba with container terminals of Rijeka, Koper and Trieste, as well as with all major shopping centres in the Central and Eastern Europe (Figure 7 and 8, Table 2)

- the proximity of markets of interest in Hungary, Austria and Slovakia,

- location of terminal in the oldest railway station in Croatia with the border crossing of Kotoriba (Croatia) - Murakeresztur (Hungary)

- no need for large investments because of the already constructed terminal and rail infrastructure that enables parallel operation with a large number of wagons (Figure 9) 
- ability to provide a large number of services with added value,

- unlimited possibility for further expansion and terminal capacity,

- predominantly private ownership,

- low cost of the land and construction coverage zone,

- availability of good quality workforce,

- lower labour costs and

- long-time warehouse-customs terminal and customs office.

The proposed inland container terminal in Kotoriba would be based on the following development guidelines:

- storage and manipulation of different types of cargo (liquid, bulk, refrigerated, general, ...)

- provision of value added services (packaging, labelling, palletising, baling, sorting, etc.)

- establishment of the terminal as a distribution centre where cargoes from different destinations would be collected and individual shipments from containers would be forwarded,

- carrying out of customs formalities and procedures,

- enabling cargo inspections, that is, sampling for analysis of all inspections that conduct the supervision of goods,

- providing storage space for full containers with small costs of demurrage,

- creating a depot for empty containers and equipment

- opening of the repair workshop for the containers and equipment,

- cleaning and preparing the containers for loading of different types of cargo

- setting up the marshalling railway station for the formation of the train composition towards seaports and industrial centres.

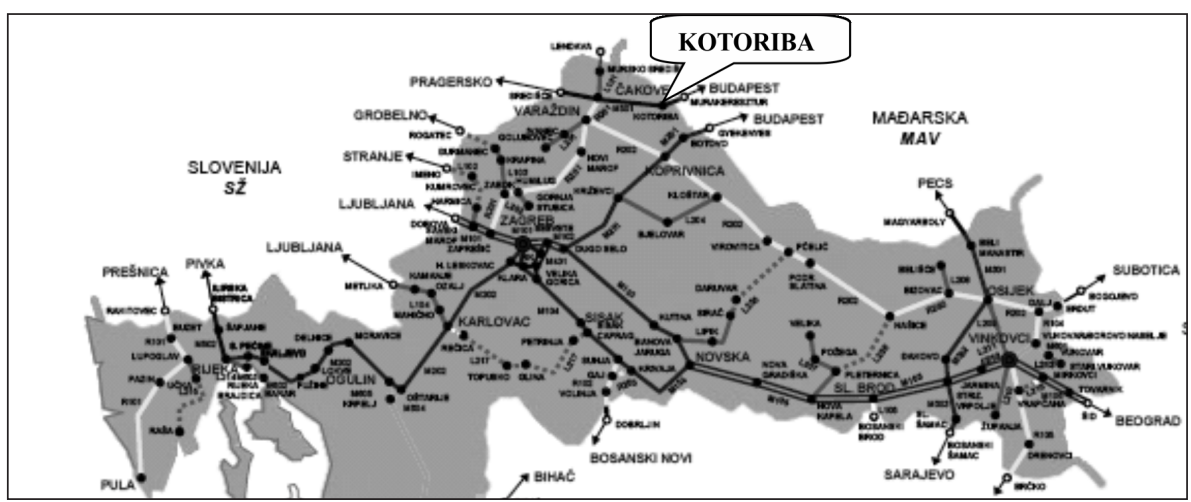

Figure 7 - Map of the railway infrastructure of Croatia [24] 
The inland terminal in Kotoriba with its important railway transport corridor is an exceptional contribution to the development of inter-modality of the Northern Adriatic to the markets of the Central and Eastern Europe. Its high quality and efficient utilization will certainly contribute to increased competitiveness and productivity of supply chains on the Northern Adriatic transport route.

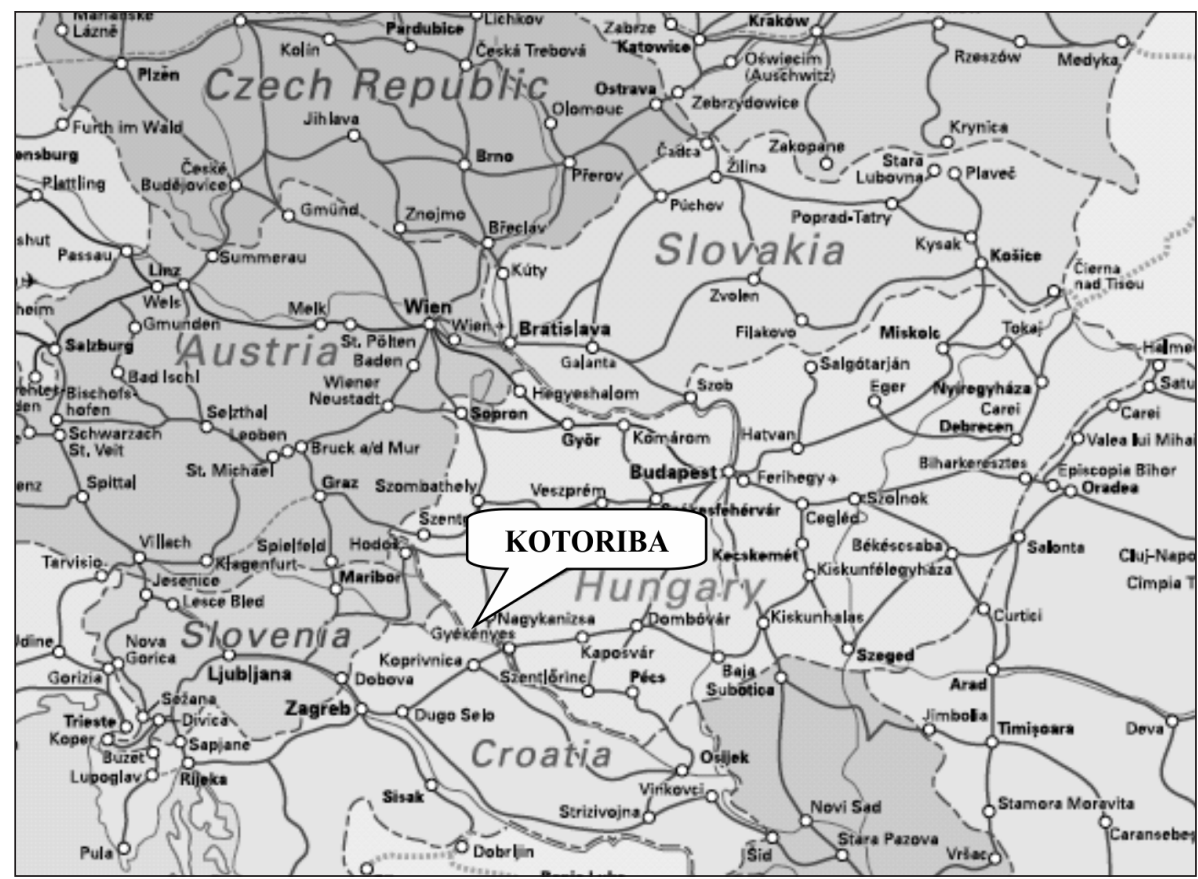

Figure 8-Map of the Central and Eastern Europe railway infrastructure [25]

The spatial distance from Kotoriba to the seaports of Rijeka, Trieste and Koper categorizes this terminal as a medium distance located inland terminal. This gives it the opportunity to develop as a transport hub in which it will unite different road and rail services, carry out all the necessary customs formalities, unify small individual wagon shipments in single block trains, organize transport to the final destination, provide a variety of value-added services, etc. 
Table 2 - Railway and road distances between Kotoriba and certain cities

\begin{tabular}{|l|c|c|}
\hline $\begin{array}{c}\text { Relations in km } \\
\text { (from Kotoriba to...) }\end{array}$ & Road distance & Railway distance \\
\hline Rijeka & 283 & 350 \\
\hline Koper & 360 & 378 \\
\hline Trieste & 349 & 365 \\
\hline Belgrade & 490 & 445 \\
\hline Budapest & 257 & 249 \\
\hline Bratislava & 290 & 270 \\
\hline Zilina & 495 & 47 \\
\hline Wien & 286 & 261 \\
\hline Kosice & 516 & 506 \\
\hline Ostrava & 576 & 533 \\
\hline Praha & 578 & 617 \\
\hline Katowice & 652 & 638 \\
\hline
\end{tabular}

Source: [26]

Potential locations of an inland container terminal are valorised in Table 3.

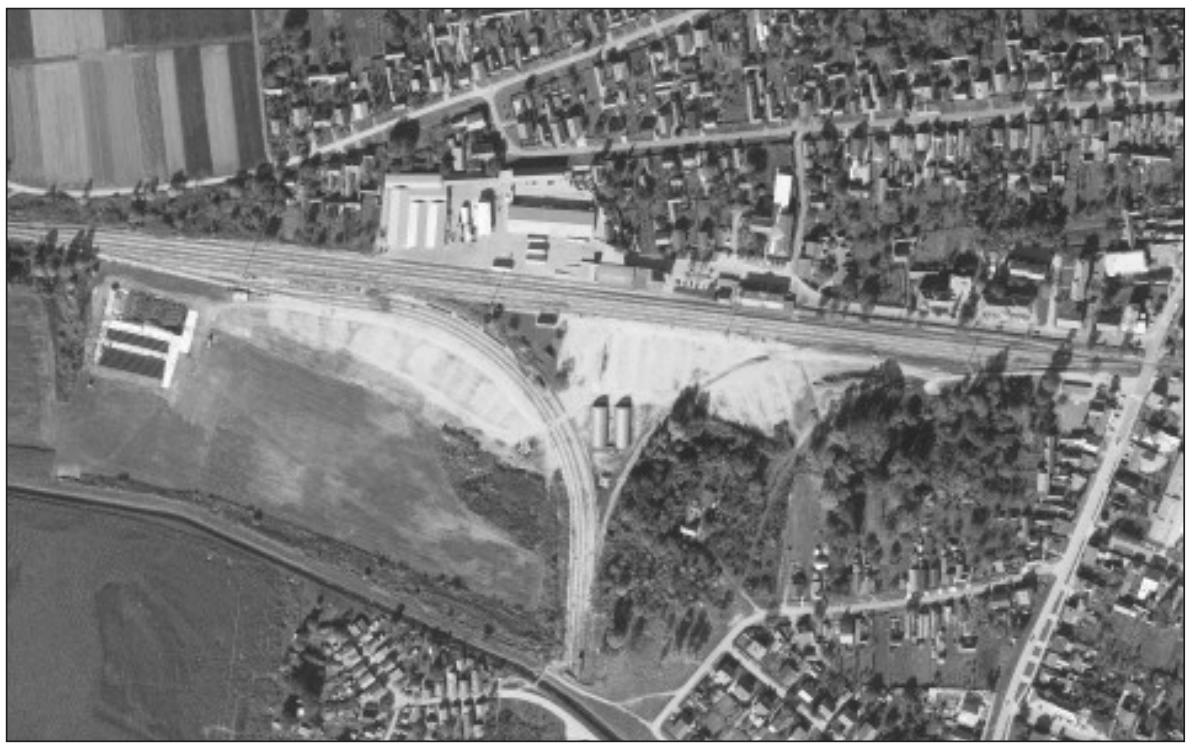

Figure 9 - The existing inland container terminal in Kotoriba [27] 
Table 3 - Comparison of criteria for selected inland terminals

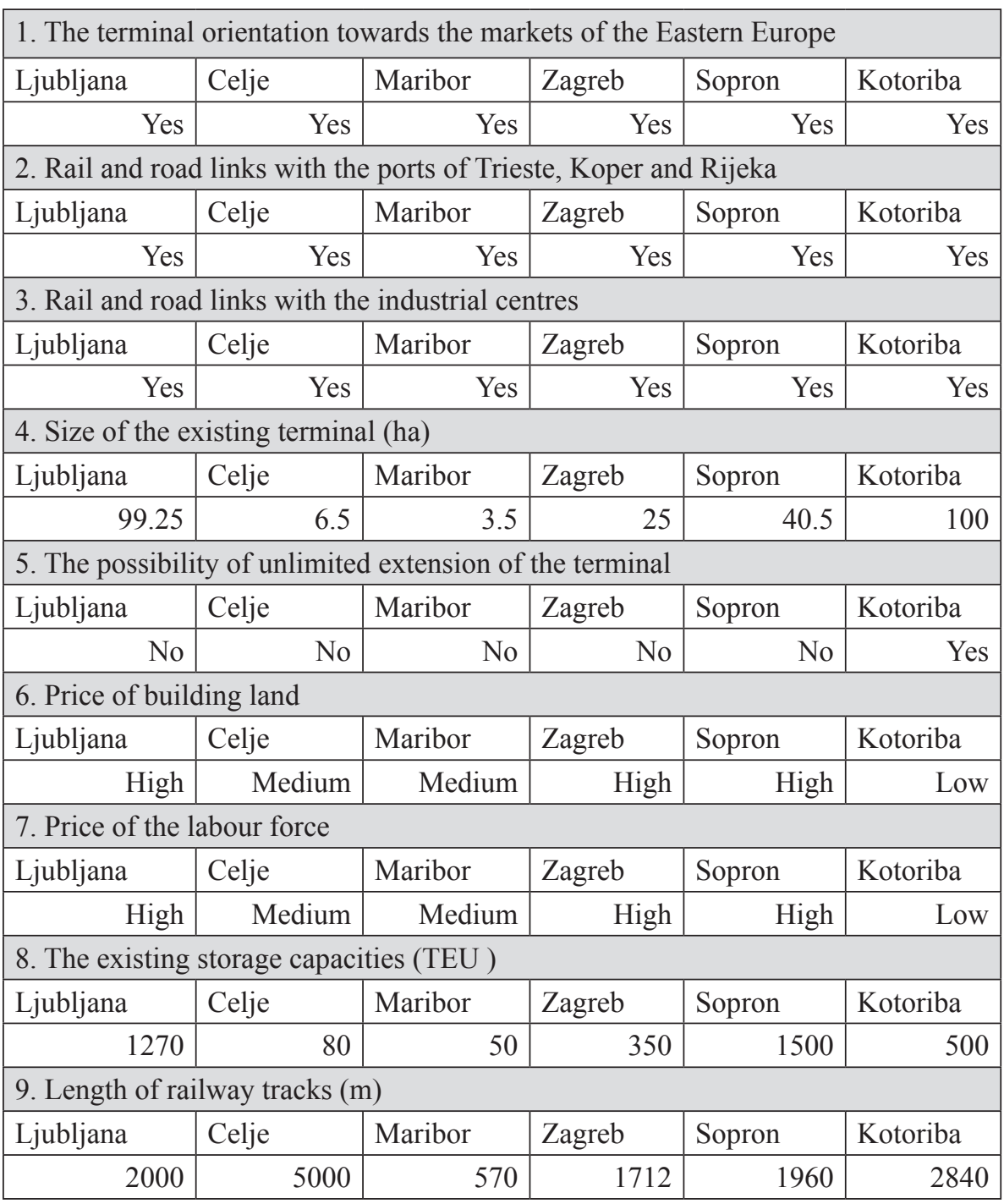

In view of the existing partial construction of inland terminals in Kotoriba, the level of additional capital investment does not require significant financial resources. Therefore, this terminal can be an important transit logistics hub oriented towards the seaports of Rijeka, Trieste and Koper which will surely contribute to the rapid economic development of the Republic of Croatia. 


\section{Conclusion}

Inland terminals with their quality of transport links with seaports provide an important logistical support in facilitating container supply chains. In addition to intermodal services and numerous service activities with added value, they provide access to more remote areas of interest. This ensures a stronger position of seaports in the competitive market and contributes to increasing their overall productivity and efficiency.

Liberalization of the international trade and the creation of a single European market, have created conditions that have a positive impact on the Northern Adriatic transport route. Due to the geographical position of the ports of Rijeka, Trieste and Koper, it is a natural route for goods to the markets of the Central and Eastern Europe and the importance of this traffic route has been increasing on a daily basis. This is also visible from the steady increase in container traffic which, according to the analyses of the potential (NAPA Container Market Study, 2011) should rise by up to $348 \%$ by 2030 .

In addition to maritime liner services towards the Northern Adriatic, all ships of larger capacity are also being introduced, which puts additional pressure on the spatially limited port capacity. In order to address the identified problems and avoid the traffic jam around the terminal, there is a need to improve land connections with the hinterland. In addition, an important role is also attached to inland terminals which can improve, together with their logistics services, the running of container traffic.

By uniting the common interests of container terminals of Rijeka, Koper and Trieste, and their stronger presence on the competitive market, the location of inland terminals in Kotoriba, Croatia has come to be true. The proposed site is located in the railway station area along the Croatian-Hungarian border with already constructed railway terminal and infrastructure and represents an ideal position as a medium-distance inland terminal. Direct road and rail connections with sea ports and with markets of the Central and Eastern Europe guarantee secure business profitability and transport justification. With minimal financial investment, excellent transport and logistics impacts can be achieved and significantly improve the running of the Northern Adriatic supply chain. This would meet the guidelines of the European infrastructure policy that require a higher quality connection of port terminals to the land transportation system in order to make traffic junctions on the European coast more accessible and ensure a balanced distribution of incoming and outgoing flows of goods in the European transport system. 


\section{References}

1. UNECE, Hinterland connections of sea port, United Nations, New York \& London, 2010

2. The World Bank [cited 2015 Jan 11]. Available from: http://data.worldbank.org

3. Talley WK. Port economics. New York; 2009

4. World Shipping Council [cited 2015 Jan 11]. Available from: http://www.worldshipping.org

5. Roso V, Lumsden K. A review of dry ports. Maritime Economics \& Logistics. 2010; 12(2): 196213.

6. Iannone F. Dry ports and the extended gateway concept: port-hinterland container network design considerations and models under the shipper perspective. [Internet] 2013 [cited 2015 Jan 7]. Available from: http://papers.ssrn.com

7. Acciaro M, McKinnon A. Efficient hinterland transport infrastructure and services for large container ports. Prepared for the roundtable on RT port investment and container shipping markets roundtable, discussion paper no.19; Nov 2013; Santiago, Chile.

8. Notteboom T. The relationship between seaports and the inter-modal hinterland in light of global supply chains: European challenges. Paper presented at research roundtable „Seaport competition and hinterland connections" OECD/ITF; 2008 April; Paris, France.

9. Roso V, Woxenius J, Lumsden K. The dry port concept: connecting container seaports with the hinterland. Journal of Transport Geography. 2009; 17(5): 338-345.

10. Van der Horst M, De Langen P. Coordination in hinterland transport chains: a major challenge for the seaport community. Maritime economics and logistics. 2008; 10(1-2): 108-129.

11. Jaržemskis A, Vasiliauskas A.V. Research on dry port concept as intermodal node. Transport. 2007; 22(3): 207-213.

12. Garnwa P, Beresford A, Pettit S. Dry ports: a comparative study of the United Kingdom and Nigeria. Transport and Communications Bulletin for Asia and the Pacific. 2009; 78; United Nations ESCAP.

13. Rožić T, Petrović M, Ogrizović D. Container transport flows as a prerequisite for determination of inland terminal location. Scientific Journal of Maritime Research. 2014; 28(1): 3-9.

14. De Villiers G, Mackay J, Serafino L. Inland intermodal terminals and freight logistic hubs. Civil Engineering. 2013; 21(8): 17-20.

15. Guidelines for setting up Inland Container Depot (ICD) and Container Freight Station (CFS) in India. Government of India, Ministry of Commerce \& Industry, Department of Commerce [Internet] 2014 [cited 2015 Jan 21]. Available from: http://commerce.nic.in

16. NAPA Market study on the potential cargo capacity of the North Adriatic ports system in the container sector. MDS, Transmodal limited. 2011. Available from: http://www.its-napa.eu

17. Luka Rijeka. [cited 2015 Jan 14] Available from: www.lukarijeka.hr

18. Luka Koper. [cited 2015 Jan 14] Available from: www.luka-kp.si

19. Porto di Trieste. [cited 2015 Jan 14] Available from: www.porto.trieste.it

20. Porto di Ravenna. [cited 2015 Jan 14] Available from: www.port.ravenna.it

21. Porto di Venezia. [cited 2015 Jan 14] Available from: www.port.venice.it

22. North Adriatic Ports Association. [cited 2015 Jan 14]. Available from http://www.portsofnapa.com

23. AGORA Intermodal Terminals. [cited 2015 Jan 30]. Available from: http://www.intermodalterminals.eu

24. HŽ Infrastruktura [cited 2015 Jan 31]. Available from: http://www.hzinfra.hr/karta-pruga

25. Eurail. [cited 2015 Jan 31]. Available from: http://www.eurail.com

26. Michelin. [cited 2015 Jan 31]. Available from: http://www.viamichelin.com

27. Preglednik. [cited 2015 Jan 31]. Available from http://preglednik.arkod.hr 


\section{Kopneni kontejnerski terminali u funkciji uspješnijeg poslovanja sjevernojadranskih luka}

\section{Sažetak}

Kontinuirani rast kontejnerskog prometa luka sjevernog Jadrana uzrokovao je visoku iskoristivost postojećih prekrcajnih i skladišnih kapaciteta. U cilju rasterećenja takvog pritiska i izbjegavanja prometnih zagušenja i prekapacitiranosti koja se već pojavljuju, kao moguće rješenje nameće se izgradnja novog kopnenog kontejnerskog terminala u njihovom gravitacijskom zaleđu. Time bi se zadovoljile potrebe za dodatnim skladišnim prostorima, ubrzao protok kontejnera i osigurao održivi razvoj sjevernojadranskih kontejnerskih luka. U ovom radu dan je prijedlog razvitka kopnenog kontejnerskog terminala u Kotoribi kao tranzitnog logističkog centra za luke Rijeka, Trst i Kopar. Koristeći koncept njihovog međusobnog prometnog povezivanja i poslovnu politiku zajedničkog tržišnog nastupanja osigurat će se neograničene mogućnosti u razvoju sjevernojadranskog opskrbnog lanca prema tržištima srednje $\mathrm{i}$ istočne Europe.

Ključne riječi: kopneni kontejnerski terminali, sjevernojadranski opskrbni lanci, logističko planiranje, intermodalni transport 